\title{
Preoperative Evaluation of Lung Cancer Patients
}

\author{
Marc Licker · Frédéric Triponez · John Diaper • \\ Wolfram Karenovics • Pierre-Olivier Bridevaux
}

Published online: 12 February 2014

(C) Springer Science + Business Media New York 2014

\begin{abstract}
Preoperative assessment of patients scheduled for lung resection focuses on four main areas: cardiac risk, lung mechanical function, gas exchange capacity and cardio-pulmonary reserve. Physiological measurements of lung volumes and diffusion capacity combined with lung imaging studies are helpful to estimate postoperative pulmonary function. Maximal oxygen capacity and physical fitness are better predictors of major postoperative complications and long-term survival.
\end{abstract}

Keywords Lung cancer - Thoracotomy - Lung resection · Spirometry $\cdot$ Lung diffusion capacity · Cardio-pulmonary exercise test - Maximal oxygen consumption $\left(\mathrm{VO}_{2} \mathrm{max}\right)$. Anesthesia

\section{Introduction}

Lung cancer is the second most common cancer and is by far the leading cause of cancer death in both men and

M. Licker $(\bowtie) \cdot$ J. Diaper

Department of Anesthesiology, Pharmacology and Intensive Care Medicine, University Hospital of Geneva, rue GabriellePerret-Gentil, 1211 Geneva 14, Switzerland

e-mail: marc-joseph.licker@hcuge.ch

M. Licker · F. Triponez · P.-O. Bridevaux

Faculty of Medicine, University of Geneva, Geneva 14,

Switzerland

F. Triponez $\cdot$ W. Karenovics

Department of Thoracic Surgery, University Hospital of Geneva,

University of Geneva, Geneva 14, Switzerland

P.-O. Bridevaux

Department of Chest Medicine, Hospital du Valais, Sion,

Switzerland women. In 2010, 201,144 new cases of lung cancer were diagnosed in the USA, with a death toll of 158,248 persons [1]. ${ }^{1}$ Despite progress in lung imaging and advances in radio-chemotherapies, the 5-year survival rate of patients with non-small cell lung cancer (NSCLC) remains low: $16 \%$ in the US and even less in the UK (7.8\%) [2]. Surgical resection is still the best therapeutic option that can be offered in 10-25\% of patients with early stages of NSCLC. In the remaining patients, the disease is considered too advanced or comorbidities are judged too severe, precluding any benefit in terms of postoperative survival and quality of life $[3,4]$. The current rate of operative mortality ranges between 1.6 and $7 \%$ with a high incidence of cardiopulmonary complications (20-40\%) resulting in prolonged hospital stay and increased health care costs $[5,6]$. Scoring tools predicting operative mortality emphasize the importance of age, performance status, procedure type, lung function and comorbidities (Table 1) $[7 \cdot, 8,9 \cdot]$.

\section{Cardiac Assessment}

Supra-ventricular arrhythmias are the most frequent postoperative complications (5-25\%), particularly after pneumonectomy and in elderly patients [10]. Other less frequent cardiac complications, such as myocardial infarction, heart failure and ventricular fibrillation (2-3\%), are the second cause of operative death after respiratory failure $[11,12]$. As a consequence, cardiac risk stratification should always be performed preoperatively. Based on the guidelines of the American College of Cardiology and the American Heart Association [13], surgery should be

\footnotetext{
${ }^{1}$ http://www.cdc.gov/cancer/lung/statistics/.
} 
Table 1 Prediction score of 30-day mortality after lung surgery (Thoracoscore)

\begin{tabular}{|c|c|c|c|}
\hline Variable & Value & Code & \\
\hline \multirow[t]{3}{*}{ Age (years) } & $<55$ & 0 & \\
\hline & $55-65$ & 1 & \\
\hline & 65 & 2 & \\
\hline \multirow[t]{2}{*}{ Sex } & Female & 0 & \\
\hline & Male & 1 & \\
\hline \multirow[t]{2}{*}{ ASA score } & 1,2 & 0 & \\
\hline & 3,4 & 1 & \\
\hline \multirow{2}{*}{$\begin{array}{l}\text { Performance } \\
\text { status } \\
\text { classification } \\
(0-4)^{\mathrm{a}}\end{array}$} & $\leq 2$ & 0 & \multirow{2}{*}{$\begin{array}{l}0 \text { (normal) to } 4 \text { (unable } \\
\text { to leave the bed/chair) }\end{array}$} \\
\hline & $\geq 3$ & 1 & \\
\hline \multirow{2}{*}{$\begin{array}{l}\text { Dyspnea score } \\
(0-5)\end{array}$} & $\leq 2$ & 0 & \multirow{2}{*}{$\begin{array}{l}0 \text { (no dyspnea) to } 5 \\
\text { (breathless when } \\
\text { dressing or eating) }\end{array}$} \\
\hline & $\geq 3$ & 1 & \\
\hline \multirow{2}{*}{$\begin{array}{l}\text { Priority of } \\
\text { surgery }\end{array}$} & Elective & 0 & \\
\hline & Emergency & 1 & \\
\hline \multirow[t]{2}{*}{ Procedure class } & Other & 0 & \\
\hline & Pneumonectomy & 1 & \\
\hline \multirow{2}{*}{$\begin{array}{l}\text { Diagnosis } \\
\text { group }\end{array}$} & Benign & 0 & \multirow[b]{2}{*}{$\begin{array}{l}\text { History of cancer, } \\
\text { smoking, COPD, } \\
\text { hypertension, heart } \\
\text { disease, diabete } \\
\text { mellitus, peripheral } \\
\text { vascular disease, } \\
\text { obesity, and } \\
\text { alcoholism }\end{array}$} \\
\hline & Malignant & 1 & \\
\hline
\end{tabular}

http://www.sfar.org/scores2/thoracoscore2.html

a Adapted from World health Organization and Zubrod score

0 - Asymptomatic (Fully active, able to carry on all predisease activities without restriction)

1 - Symptomatic but completely ambulatory (restricted in physically strenuous activity but ambulatory and able to carry out work of a light or sedentary nature)

2 - Symptomatic, $<50 \%$ in bed during the day (ambulatory and capable of all self care but unable to carry out any work activities)

3 - Symptomatic, $>50 \%$ in bed, but not bedbound (capable of only limited self-care, confined to bed or chair $50 \%$ or more of waking hours)

4 - Bedbound (completely disabled and confined to bed or chair)

deferred (or cancelled) in patients with major risk factors (e.g., recent myocardial infarction, ongoing ischemia, untreated heart failure), whereas those with intermediate risk factors should undergo further medical assessment and therapeutic optimization (Fig. 1). The revised cardiac risk index entails six independent risk predictors of cardiac complications (major surgery, coronary artery disease, heart failure, diabetes mellitus, renal dysfunction and history of stroke). A modified version has been proposed and validated specifically for thoracic surgical patients $[14,15]$.

Patients with coronary stents requiring aggressive antiplatelet therapy represent a major challenge given the risks of perioperative bleeding and intra-stent thrombosis [16]. Patients with pulmonary hypertension $(\mathrm{PH})$ also deserve special consideration given the increased right ventricular load resulting from one-lung ventilation and surgical resection. Although increased mortality has been demonstrated in patients with moderate-to-severe $\mathrm{PH}$ undergoing noncardiac surgery [17, 18], favourable outcomes have recently been reported following lobectomy in patients with moderate $\mathrm{PH}$ and normal right ventricular function [19].

\section{Pulmonary Assessment}

Multivariate analysis in large cohorts of non-cardiac surgical patients revealed that the occurrence of postoperative pulmonary complications was mainly associated with the severity of the lung disorder [e.g., fibrosis, asthma, chronic obstructive lung disease (COPD), recent pneumonia, pulsed oxygen saturation less than $93 \%$ ], heart failure, morbid obesity, impaired physiological condition (poor exercise capacity, recent weight loss, anemia, hypoalbuminemia) as well as corticosteroid treatment, smoking habits and alcohol consumption [6, 12] [20-22].

\section{Lung Volumes, Gas Flow and Airway Resistance}

With modern pneumotachographs, inspiratory and expiratory airflow rates can easily be measured and digitally converted into lung volumes $\left(\mathrm{V}=\int \mathrm{Vd} t\right)$. Flow/volume curves are displayed, and a tabular chart includes the following items: forced or slow vital capacity (FVC, SVC), forced expiratory volume over the first second $\left(\mathrm{FEV}_{1}\right)$, ratio of $\mathrm{FEV}_{1}: \mathrm{FVC}$, peak airflow (PEF) and forced expiratory flow at 50,75 or $25-75 \%$ of lung vital capacity $\left(\mathrm{FEF}_{50}, \mathrm{FEF}_{75}, \mathrm{FEF}_{25-75}\right)$ [23]. These physiological parameters are expressed in raw values and percent predicted as compared with subjects having similar characteristics (body weight, height, age and gender) [24].

Whole-body plethysmography and insoluble gas dilution techniques (using nitrogen or helium) are common methods that are used to assess "non-mobilizable" volumes, [functional residual volume and the residual volume (RV)]. The difference in measured lung volume between the two techniques is useful to estimate the volume of emphysematous bullae.

In restrictive pulmonary disorders (e.g., interstitial fibrosis, morbid obesity, neuromuscular disease), all lung volumes are decreased but the airway conductance is minimally altered. In obstructive pulmonary disorders, limitation in maximal airflow rates is best characterized by reductions in $\mathrm{FEV}_{1}$ and the $\mathrm{FEV}_{1}: \mathrm{FVC}$ ratio with RV and FRC being increased in emphysema while remaining relatively unchanged in chronic bronchitis [25, 26•,27]. Repetition of 
Fig. 1 Algorithm for preoperative assessment of patient undergoing lung surgery

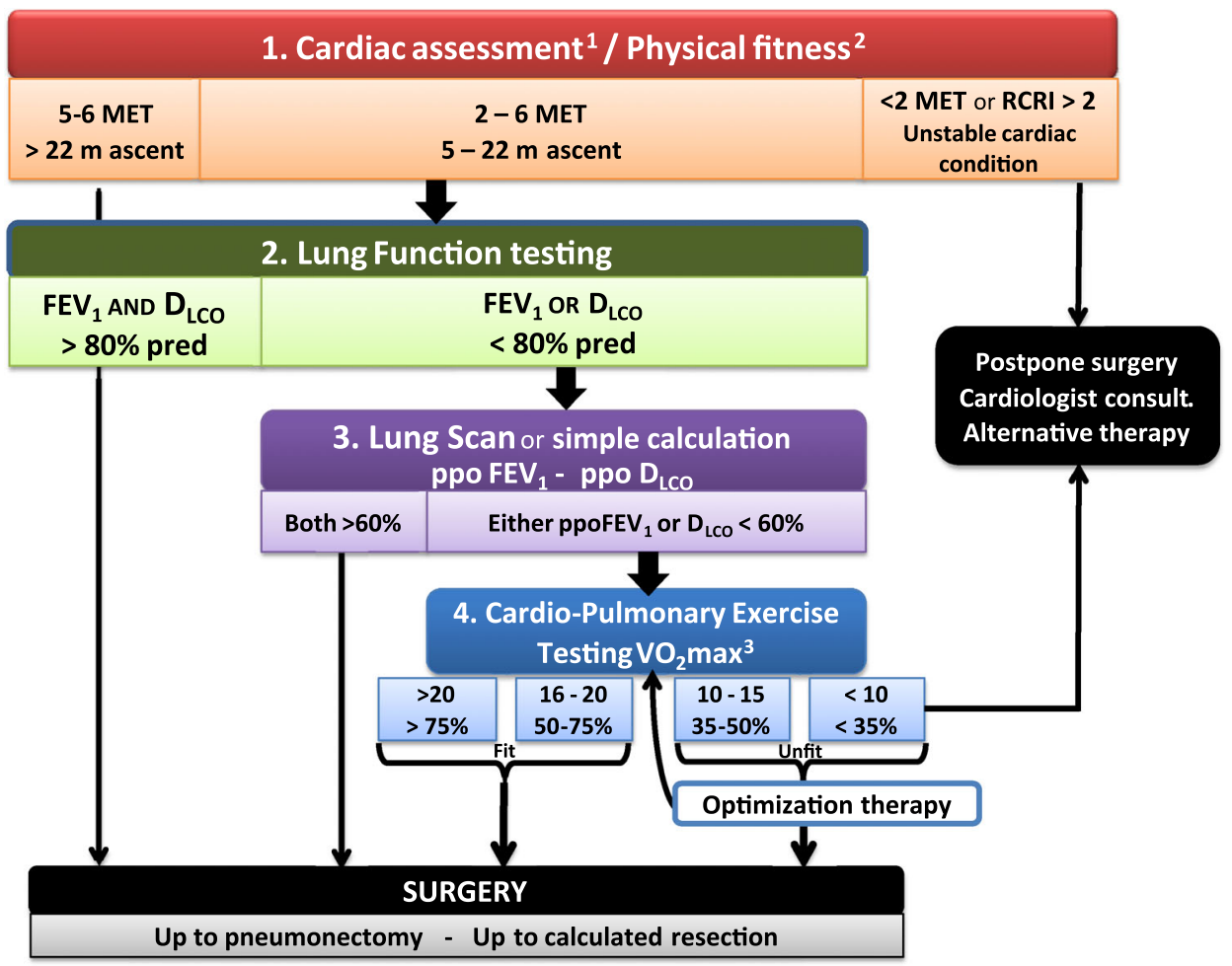

Revised cardiac risk index (RCRI) ${ }^{1, a}$

Thoracic RCRI $^{b}$

High risk surgery

$1 \mathrm{pt}$

Pneumonectomy

$1.5 \mathrm{pt}$

Coronary artery disease

$1 \mathrm{pt}$

Coronary Artery disease

$1.5 \mathrm{pt}$

Congestive heart failure:

$1 \mathrm{pt}$

Cerebrovascular disease:

$1 \mathrm{pt}$

Cerebrovascular disease:

$1.5 \mathrm{pt}$

Diabetes mellitus on insulin:

$1 \mathrm{pt}$

Serum creatinine $>2 \mathrm{mg} / \mathrm{dl}$

$1 \mathrm{pt}$

Serum creatinine $>2 \mathrm{mg} / \mathrm{dl}$

$1 \mathrm{pt}$

${ }^{\text {a }}$ Cardiac arrest, ventric. Fibrillation, complete heart block, Myoc. Infarct, pulmonary emblism

${ }^{\mathrm{b}}$ Cardiac arrest, complete heart block, Myoc. Infarct, pulmonary edema

\footnotetext{
${ }^{1, a}$ RCRI: 0-1pt, low risk of mortality $(0.8 \%, 95 \%$ confidence interval [CI] 0.3-1.3); 2 pts, moderate risk (2.4\%, $95 \% \mathrm{Cl} 1.3-3.5 \%) ;>2$ pts, high risk (5.4\%, $95 \% \mathrm{Cl} 2.8-7.9 \%)$

${ }^{\mathrm{b}}$ TRCRI: 0 pt, low risk of mortality (<5 \%); 1-1.5 pts, moderate risk (5-10\%); 2-2.5 pts (11-20\%); 2.5 pts (>20\%)

${ }^{2}$ Physical fitness: metabolic equivalent $\left(1 \mathrm{MET}=3.5 \mathrm{ml} \mathrm{kg}^{-1} \mathrm{~min}^{-1}\right)$, stair climbing (number of stairs,

height of ascent in meter), six-minute walk test (meters), shuttle walk test (meters)

${ }^{3} \mathrm{VO}_{2}$ max expressed in $\mathrm{ml} \mathrm{kg}^{-1} \mathrm{~min}-1$
}

spirometric tests following inhalation of bronchodilating or bronchoconstrictive agents may detect hyperreactive airways and ascertain the efficacy of treatment with $\beta_{2}$-adrenergic agonists, anticholinergic agents or steroids. Analysis of inspiratory/expiratory flow-volume curves may be helpful to document the severity and the site of airway obstruction (small/large airways, intra-/extrathoracic). Diagnosis and assessment of the severity of COPD are largely based on clinical signs (dyspnea, sputum production) and post-bronchodilator $\mathrm{FEV}_{1} / \mathrm{FVC}$ and $\mathrm{FEV}_{1}$ measurements (Table 2)
$[26 \bullet, 28]$. Monitoring the disease progression and predicting life expectancy can best be achieved using multidimensional instruments such as the BODE index, which takes into account the severity of airway obstruction, dyspnea, age as well as nutritional status and exercise tolerance [29, 30].

\section{Lung Gas Exchange Assessment}

The diffusion capacity of carbon oxide $\left(\mathrm{D}_{\mathrm{LCO}}\right)$ reflects the overall ability of the lung to transport gas into and out of the 
Table 2 GOLD classification of chronic obstructive pulmonary disease

\begin{tabular}{lll}
\hline Stage of COPD & Test results & Signs \\
\hline 0: at risk & Normal lung test & Coughing up mucus, every day for some time \\
1: Mild & $\mathrm{FEV}_{1} / \mathrm{FVC}<0.7$ & Cough + \\
& $\mathrm{FEV}_{1}>80 \%$ & A little breathless when walking quickly \\
& $\mathrm{FEV}_{1} / \mathrm{FVC}<0.7$ & Cough ++ \\
2: Moderate & $\mathrm{FEV}_{1} 50-80 \%$ & Breathless if working hard, walking quickly \\
& & or doing household jobs \\
& $\mathrm{FEV}_{1} / \mathrm{FVC}<0.7$ & Difficult working physically, fatigability ++ \\
3: Severe & $\mathrm{FEV}_{1} 30-50 \%$ & Impaired exercise tolerance \\
& $\mathrm{FEV}_{1} / \mathrm{FVC}<0.7$ & Unable to to go to work or do jobs \\
4: Very severe & $\mathrm{FEV}_{1} 30-50 \%$ with other & Difficult to walk across the room \\
& signs of lung failure & \\
& $\mathrm{FEV}_{1}<30 \%$ & Possible cor pulmonale \\
\hline
\end{tabular}

$F E V_{l}$ Forced expiratory volume in the first second; $F V C$ forced vital capacity cardiovascular impairments. In the recent Spanish cohort ARISCAT study [20], a low preoperative value of arterial pulsed oxygen saturation $\left(\mathrm{SpO}_{2}<94 \%\right)$ was identified as a strong predictor of pulmonary complications after non-cardiac surgery. The associated increase in the alveolar-arterial $\mathrm{PO}_{2}$ gradient $\left(\mathrm{AaPaO}_{2}>10 \mathrm{mmHg}\right)$ often reflects regional heterogeneities in ventilation/perfusion that are associated with COPD or restrictive lung diseases [37]. Hypoxemia refractory to $\mathrm{O}_{2}$ therapy is a characteristic feature of a true shunt or "venous admixture" that can be related to congenital vascular abnormalities, paraneoplasic syndrome, pleural effusion, large atelectasis or liver failure [38].

There is a poor correlation between $\mathrm{FEV}_{1}$ and $\mathrm{D}_{\mathrm{LCO}}$. For example, low $\mathrm{D}_{\mathrm{LCO}}$ values $(<80 \%)$ are encountered in up to $50 \%$ of patients with normal $\mathrm{FEV}_{1}$ [39]. Hence, guidelines from the British Thoracic Society (BTS) [40], the American Chest Physician (ACCP) and the European Respiratory Society (ERS) [41] all recommend that lung volumes and $\mathrm{D}_{\mathrm{LCO}}$ should be measured in patients undergoing lung resection.

In the early stages of interstitial infiltrative lung diseases, spirometric results are barely affected, whereas $\mathrm{D}_{\text {LCO }}$ already exhibits significant impairment [42]. The reverse holds true in COPD where $\mathrm{FEV}_{1}$ and the $\mathrm{FEV}_{1}: \mathrm{FVC}$ ratio both reflect the severity of the disease, while impairment of the diffusion capacity occurs at the more advanced stages. The $\mathrm{D}_{\mathrm{LCO}}$ also helps in the differential diagnosis of restrictive lung disease: normal values are reported in patients with extrapulmonary causes (e.g., obesity, neuromuscular disease, pleural effusion), and low $\mathrm{D}_{\text {LCO }}$ values are found in interstitial pulmonary disorders.

\section{Estimation of Postoperative Respiratory Function}

A simple method of estimating the predicted postoperative $\mathrm{FEV}_{1}$ and $\mathrm{D}_{\mathrm{LCO}}$ (ppoFEV ${ }_{1}$ and ppoD $\mathrm{LCO}_{\mathrm{LO}}$, respectively) is

based on counting the number of functional segments (nine

\footnotetext{
${ }^{2} \mathrm{D}_{\mathrm{LCO}}=\mathrm{V}_{\mathrm{CO}} / \mathrm{P}_{\mathrm{ACO}}$ where and $1 / \mathrm{D}_{\mathrm{LCO}}=1 / \mathrm{D}_{\mathrm{M}}+1 / \theta ; \mathrm{Vc}$ where $\mathrm{D}_{\mathrm{LCO}}=$ diffusion capacity; $\mathrm{V}_{\mathrm{CO}}=$ disappearance rate of CO; $\mathrm{P}_{\mathrm{ACO}}=$ alveolar concentration of $\mathrm{CO} ; \mathrm{Vc}$, capillary blood volume; $\theta$, reaction rate with hemoglobin
}

A landmark cohort study in the mid-1970s showed that preoperative hypercapnia was associated with prolong failed to identify impaired $\mathrm{CO}_{2}$ clearance as a risk factor for unplanned admission to the ICU or need for mechanical hypercapnia $\left(\mathrm{PaCO}_{2}>7.5 \mathrm{kPa}\right)$ is a key feature of respiratory failure from any cause, these patients are usually not considered for major lung resection and are referred to nonurgical treatments and/or rehabilitation programs.

In contrast with other functional parameters, arterial oxygen pressure $\left(\mathrm{PaO}_{2}\right)$ is weakly influenced by aging [36]. Hypoxemia is a common marker of respiratory and/or 
in the left lung and ten in the right lung) or subsegments. Assuming that all lung areas contribute equally to the overall lung function, the preop $\mathrm{FEV}_{1}$ value (or preop $\mathrm{D}_{\mathrm{LCO}}$ ) is multiplied by the number of segments (or subsegments) remaining after surgery [43]. Correction can be made by subtracting the number of obstructed segments as seen at CT scan or bronchoscopy.

Quantitative perfusion scans represent the reference methods for assessing the contribution of each lung (or part of the lung) to overall function [44]. After administration of intravenous macroaggregates labelled with technetium, the perfusion of the radiotracer(s) is measured through the lungs, and specific formulas are used to calculate ppoFEV $_{1}$ or ppoDLCO. $^{3}$ More recently, quantitative computed tomography, magnetic resonance scanning, single photon emission computed tomography (SPECT) or a combination of them have yielded acceptable results in predicting ppo$\mathrm{FEV}_{1}$ as compared with perfusion scintigraphy $[45,46]$.

The BTS recommends that imaging-based calculation of residual lung function should only be performed in patients with an $\mathrm{FEV}_{1}<80 \%$ and scheduled for pneumonectomy [40]. In contrast, the more recent ERS and ACCP guidelines recommend that all patients with borderline function $\left(\mathrm{FEV}_{1}\right.$ or $\mathrm{D}_{\mathrm{LCO}}<80 \%$ and limited exercise capacity) and scheduled for any major resection (lobectomy or pneumonectomy) should undergo imaging-based calculation of $\operatorname{ppoFEV}_{1}$ and $\operatorname{ppoD}_{\mathrm{LCO}}[41,47 \cdot]$.

The maximal decline in $\mathrm{FEV}_{1}$ (approximately -20 to $40 \%$ after lobectomy, -40 to $60 \%$ after pneumonectomy) is reached in the immediate postoperative period when the depressive respiratory effects of anesthesia are added to the effects of lung resection [48]. This functional impairment can be attenuated by minimally invasive surgical approaches, intraoperative ventilatory protective strategies and fast-tracking anesthetic regimens [22, 49-52]. Functional recovery continues for approximately 6 months after lobectomy $\left(\mathrm{FEV}_{1}\right.$ up to $84-91 \%$ of preoperative baseline values, $\mathrm{D}_{\mathrm{LCO}}$ up to $89-96 \%, \mathrm{VO}_{2} \max$ up to $89-100 \%$ ), while it is usually limited to 3 months after pneumonectomy $\left(\mathrm{FEV}_{1}\right.$ up to $64-71 \%, \mathrm{D}_{\mathrm{LCO}}$ up to $77-80 \%$, $\mathrm{VO}_{2} \max$ up to $72-80 \%$ ) [53]. Importantly, an inverse relationship has been found between baseline severity of airflow obstruction and postoperative reduction in $\mathrm{FEV}_{1}$. Patients with severe heterogeneous emphysema eligible for lung volume reduction surgery represent a unique subset of individuals who will tolerate curative-intent lobar or segmental resection with acceptable perioperative mortality and long-term survival [54].

\footnotetext{
3 Pneumonectomy: ppoFEV ${ }_{1}=$ preop $\mathrm{FEV}_{1} \times(1-\%$ radioactivity of the resected lung part). Lobectomy : $\operatorname{ppoFEV}_{1}=$ preop $\mathrm{FEV}_{1} \times$ (\%radioactivity of non-operated lung $+\%$ radioactivity of nonremoved operated lung).
}

\section{Assessment of Physical Fitness}

\section{Cardiopulmonary Exercise Testing (CPET)}

Formal CPET represents the "gold standard" method to assess the patient's physiological reserve. The scientific rationale is that "unfit" subjects might not be able to sustain the postoperative physiological impairments and the neuroendocrine and inflammatory responses induced by the surgical stress, this subset of patients being therefore at highest risk of complications [55].

This non-invasive test is routinely performed on a bicycle ergometer or on a treadmill. CPET explores the functional interactions among the lungs (gas exchange), cardiovascular system (oxygen transport) and skeletal muscles $\left(\mathrm{O}_{2}\right.$ diffusion and utilization, aerobic metabolism). After baseline measurements and a 3-min "warm-up" period, the workload is progressively incremented $(25-\mathrm{W}$ steps) over 10-15 min until the limits of exertion have been reached or the predicted maximal heart rate achieved. The CPET is interrupted earlier if myocardial ischemia, high blood pressure or cardiac arrhythmias are detected or if the patient complains of dizziness, fainting or angina pectoris [56].

During CEPT, the physiological reserves of the heart, lungs and skeletal muscles are quantified by monitoring ECG changes, heart rate and blood pressure responses, by measuring respiratory volumes, breath-by-breath $\mathrm{O}_{2}$ uptake and $\mathrm{CO}_{2}$ production as well as grading dyspnea and subjective feelings [57]. The maximal oxygen consumption $\left(\mathrm{VO}_{2} \mathrm{max}\right)$ achieved at the highest workload is expressed in relation to the total/ideal body weight (in $\mathrm{ml} \times \mathrm{min}^{-1} \times \mathrm{kg}^{-1}$ ), as a percentage of a predicted normal value $\left(\% \mathrm{VO}_{2} \mathrm{max}\right.$ pred), and it can be converted in the metabolic equivalent task $\left(\mathrm{MET}=\mathrm{VO}_{2} \mathrm{max} / \mathrm{VO}_{2}\right.$ rest $)$. The predicted normal $\mathrm{VO}_{2} \max$ takes into account patient's age, gender and height. In addition to $\mathrm{VO}_{2} \max$, the peak heart rate (peakHR) and $\mathrm{HR}$ reserve ${ }^{4}, \mathrm{O}_{2}$ pulsed saturations $\left(\mathrm{VO}_{2} / \mathrm{HR}\right)$, maximal minute ventilation, breathing equivalents $\left(\mathrm{VE} / \mathrm{VCO}_{2}\right.$ and $\left.\mathrm{VE} / \mathrm{VO}_{2}\right)$, anaerobic threshold (AT) and respiratory gas exchange ratio $\left(\mathrm{VCO}_{2}: \mathrm{VO}_{2}\right)$ are calculated to characterize the patient's aerobic capacity and physical fitness [58].

Poor tolerance to aerobic physical activities is a good indicator of general health status, particularly among COPD patients [59]. Interpretation of abnormal results during CPET is helpful for detecting significant coronary artery disease, ventricular or valvular dysfunction, gas exchange or ventilation abnormalities as well as muscle

\footnotetext{
$\overline{{ }^{4} \mathrm{HR} \text { reserve }}(\%)=($ HRpeak exercise $-\mathrm{HR}$ at rest $) / \mathrm{HRmax}-\mathrm{HR}$ at rest; HRmax $=220$-age (years) in a healthy untrained 70-year-old male (height $170 \mathrm{~cm}$, weight $70 \mathrm{~kg}$ ), the estimated $\mathrm{VO}_{2}$ max is 27.14 $\mathrm{ml} / \mathrm{kg} / \mathrm{min}$.
} 
deconditioning $[60,61]$. Physically "inactive" subjects and those with infectious and inflammatory disorders (e.g., cancer, atheromatosis, COPD, congestive heart failure) are prone to develop skeletal muscle dysfunction characterized by reduced muscular mass (sarcopenia), poor muscular strength and early release of lactate during exercise $\left(\mathrm{AT}<70 \%\right.$ ) [62]. Both $\mathrm{VO}_{2} \max$ and $\mathrm{AT}$ are enhanced following endurance physical training [63].

\section{Alternative Assessment of Exercise Capability}

Complete laboratory CPET is time consuming; it requires technical equipment and specialized resources, which are not readily available in many hospitals. Therefore, low technology exercise tests have been developed to provide surrogates for assessing patient's physical fitness [64].

Stair climbing is the simplest test where the patient is asked to climb the stairs as quickly as possible-and without pause-until fatigue, maximal dyspnea (Borg scale) or uncomfortable symptoms are achieved. Physical fitness is rated as the number of stairs or preferably the height of ascent (meters). The speed of ascent $(>15 \mathrm{~m} / \mathrm{min})$ and the ability to climb at least 20-22 $\mathrm{m}$ (or 5-6 flights of stairs) correlates with a $\mathrm{VO}_{2} \max >20 \mathrm{ml} \times \min ^{-1} \times \mathrm{kg}^{-1}$ (Table 4) [65, 66]. The HR and pulsed $\mathrm{O}_{2}$ saturation $\left(\mathrm{SpO}_{2}\right)$ are monitored throughout the test. The inability to climb three flights of stairs or the occurrence of oxygen desaturation $(>-4 \%)$ is associated with poor prognosis and warrants further investigation.

The six-minute walk test (6MWT) consists of walking indoors as far as possible in 6 min. In many hospitals and ambulatory settings, the test is performed under the supervision of a physical therapist, along a flat straight corridor with markers to indicate the distance. Although the 6-min walking distance has been shown to provide reliable estimates of $\mathrm{VO}_{2} \max$ in healthy subjects and transplant candidates, equivocal results have been obtained regarding outcome following thoracic surgery [47•].

The shuttle walk test (SWT) is an adaptation of the 6MWT where the patient walks back and forth around two cones placed $9 \mathrm{~m}$ apart, so that the total course approximates $10 \mathrm{~m}$. Audio signals are given to the patient to stimulate the walking pace, and the test is interrupted when the patient is too breathless or after $12 \mathrm{~min}$. The SWT test is more reproducible and more correlated with $\mathrm{VO}_{2} \max$ than the $6 \mathrm{MWT}$ although it tends to underestimate $\mathrm{VO}_{2} \max$ in the lower range [67]. Several studies have shown that walking distances of 200 and $400 \mathrm{~m}$ relate to $\mathrm{VO}_{2} \max$ of 10 and $15 \mathrm{ml} \times \mathrm{min}^{-1} \times \mathrm{kg}^{-1}$, respectively [68].

CPET, SWT and symptom-limited stair climbing might not be possible in some patients owing to musculoskeletal or neurological disabilities. Questionnaires related to daily living activities [MET, Karnofsky index, Duke Activity
Table 3 Duke Activity Status Index (DASI)

Take care of yourself, that is, eat dress, bathe or use the toilet? $\quad 2.75$

Walk indoors, such as around your house?

1.75

Walk 200 yards on level ground?

2.75

Climb a flight of stairs or walk up a hill?

5.50

Run a short distance?

8.00

Do light work around the house like dusting or washing

2.70 dishes?

Do moderate work around the house like vacuuming, sweeping 3.50 floors or carrying groceries?

Do heavy work around the house like scrubbing floors or lifting or moving heavy furniture?

Do yard work like raking leaves, weeding or pushing a power 4.50 mower?

Have sexual relations?

Participate in moderate recreational activities like golf, bowling, swimming dancing, doubles tennis or throwing a ball?

Participate in strenuous sports like singles tennis, football, basketball or skiing?

$\overline{\mathrm{DASI}}=$ sum of all items peak $\mathrm{VO}_{2}=(0.43 \times \mathrm{DASI})+9.6 \mathrm{ml} / \mathrm{min}$

Status Index (DASI)] are valuable surrogates of exercise capacity testing although data involving surgical patients are still lacking. The DASI was found to correlate with $\mathrm{VO}_{2} \max [69]$, and a physical activity level exceeding eight MET was associated with a lower risk of cardiovascular events in the general population (Table 3) [70].

In elderly and frail patients, simple tests of active mobilization such as the gait speed test (time needed to walk $5 \mathrm{~m}$ distance), recording of all movement through the day (podometer) and the mini-mental test have been shown to increment the predictive power of clinical risk algorithms [71]. Recent advances in monitoring technology have also provided non-invasive methods of estimating cardiac output (finger cuff technique), which can be used on patients unable to take part in traditional exercise regimes. These devices may in the future play a role in estimating cardiac reserve during limited ward based exercise.

\section{Predictive Power of Functional Tests for Postoperative Mortality and Morbidity}

Using absolute values of $\mathrm{FEV}_{1}, \mathrm{D}_{\mathrm{LCO}}$ or $\mathrm{VO}_{2} \mathrm{max}$ is inappropriate, particularly in the elderly, who present an age-related decline in the physiological reserve, as well in females and in patients with short stature. These key functional parameters should be indexed to ideal body weight or referred to subjects with similar demographic features ( $\%$ of predicted).

Although a low $\mathrm{FEV}_{1}$ value (40-80 \% of predicted) is a good marker of COPD, contradictory results have been 
Table 4 Aerobic physical capacity and perioperative risk of complications

\begin{tabular}{lllllll}
\hline CPET peakVO2 & Stair climbing & $\begin{array}{l}\text { Shuttle } \\
\text { walk }\end{array}$ & MET & $\begin{array}{l}\text { \% HR } \\
\text { reserve }\end{array}$ & $\begin{array}{l}\text { Borg scale } \\
(0-20)\end{array}$ & $\begin{array}{l}\text { Perioperative } \\
\text { risk }\end{array}$ \\
\hline$>20 \mathrm{ml} / \mathrm{kg} / \mathrm{min}$ & Altitude $22 \mathrm{~m}(6 \mathrm{floors})$ & $>600 \mathrm{~m}$ & $>6$ & $>85$ & $18-20$ & Low \\
& Speed of ascent $>15 \mathrm{~m} / \mathrm{min}$ & & 6 & $60-85$ & $14-17$ & $12-13$ \\
$15-20 \mathrm{ml} / \mathrm{kg} / \mathrm{min}$ & $8-20 \mathrm{~m}(\sim 3-4$ floors $)$ & $400 \mathrm{~m}$ & $3-6$ & $40-60$ & $6-11$ & Moderate \\
$10-15 \mathrm{ml} / \mathrm{kg} / \mathrm{min}$ & & & 3 & $<60$ & $<6$ & High \\
$<10 \mathrm{ml} / \mathrm{kg} / \mathrm{min}$ & $3-5 \mathrm{~m}(\sim 1$ floor $)$ & & $<3$ & $<40$ & $<$ high \\
\hline
\end{tabular}

${ }^{\mathrm{a}} \mathrm{HR}$ reserve $=(\mathrm{HR}$ exercise $-\mathrm{HR}$ at rest $) /(\mathrm{HRmax}-\mathrm{HR}$ at rest $) \mathrm{HRmax}=220-$ age

Example: HR during max exercise $=120,65$-year-old patient $\rightarrow$ HR reserve $=(120-70) /(155-70)=58 \%$

published regarding its predictive power for major postoperative complications $[6,72]$. In contrast, a low diffusion capacity $\left(\mathrm{D}_{\mathrm{LCO}}<60\right.$ or $80 \%$ predicted value $)$ has been consistently associated with increased mortality and morbidity, higher admission rates in intensive care units and a worse long-term quality of life in patients undergoing major resection through thoracotomy but not through thoracoscopy $[73,74]$.

For pneumologists and thoracic surgeons, $\mathrm{ppoFEV}_{1}$ and ppo $D_{\text {LCO }}$ play a pivotal role regarding the decision to proceed to further investigations and type of treatment. Taking into account the lung functional condition and extent of the resection [73], the ppoFEV $_{1}$ or $\operatorname{ppoD}_{\mathrm{LCO}}$ should not be lower than $30 \%$ to maintain an acceptable quality of life. In emphysematous patients, a favorable "volume reduction" effect may take place resulting in unchanged or even improved $\mathrm{FEV}_{1}$ and $\mathrm{D}_{\mathrm{LCO}}$ values [75]. Mortality rates ranging from 5 to $60 \%$ have been reported when ppoFEV $_{1}$ was lower than $40 \%$, and this large mortality range underlines the implication of other confounding factors in relation to concomitant organ dysfunctions and perioperative optimizing interventions.

For the anesthesiologists, quantitative or qualitative assessment of aerobic exercise capacity is of paramount importance in risk stratification. Patients with preserved physiological reserves are better able to face stressful perioperative situations such as acute lung injuries, nosocomial infections, acute bleeding, broncho-pleural fistula and myocardial ischemia, which are mainly incriminated in perioperative death. Conversely, "unfit" patients are less capable to provide a satisfactory increase in $\mathrm{O}_{2}$ transport to meet the increased surgical stress-induced metabolic demand. Pre-existing disturbances in cardiac performance, respiratory function and oxygen utilization within the skeletal muscles may even worsen during the early postoperative period as a result of inadequate pain control, residual effects of anesthesia, fluid overload, ventilatorinduced lung injury, surgical nerve damage, reflex inhibition of diaphragmatic function and muscular fatigue associated with systemic inflammation and enhanced protein catabolism [76-78].
So far, several prospective studies have demonstrated that poor exercise tolerance, low $\mathrm{VO}_{2}$ max and reduced AT $\left(<11 \mathrm{ml} \times \mathrm{kg}^{-1} \times \mathrm{min}^{-1}\right)$ are all independent predictive factors of cardiovascular and pulmonary complications as well as early and late mortality following various surgical procedures (e.g., transplantation; bariatric, visceral, urological surgery interventions) [79-82]. Moreover, the evaluation of physical fitness (in MET) has become a reliable indicator of health status and a good predictor of cardiovascular events [83].

In patients undergoing lung cancer surgery, determination of $\mathrm{VO}_{2}$ max outperforms all other functional tests (e.g., $\mathrm{FEV}_{1}$, $\mathrm{D}_{\mathrm{LCO}}$, left ventricular ejection fraction) regarding outcome prediction and plays a key role in identifying patients deemed unsuitable for surgery and those who might benefit from therapeutic interventions [84-86]. $\mathrm{A} \mathrm{VO}_{2} \max$ of $15-16 \mathrm{ml} \times \mathrm{kg}^{-1} \times \mathrm{min}^{-1}$ is a reliable threshold to discriminate between patients at low-moderate risk and those at highvery high risk of major postoperative complications. A preoperative $\mathrm{VO}_{2} \max >20 \mathrm{ml} \times \mathrm{kg}^{-1} \times \mathrm{min}^{-1}$ (or $>22-\mathrm{m}$ ascent at stair climbing) is associated with a low risk of serious adverse events whereas patients with $\mathrm{VO}_{2} \max <10 \mathrm{ml} \times$ $\mathrm{kg}^{-1} \times \min ^{-1}$ (or $<3-5 \mathrm{~m}$ ascent at stair climbing) are at a very high risk for postoperative complications (Table 4) [84, 86-89].

\section{Conclusions}

So far, only a minority of patients with lung cancer undergo curative surgical resection $(<25 \%)$ as the diagnosis is established too late and in some patients the risk of perioperative complications outweighs the benefits of resecting a "curable" tumor.

The goal of preoperative functional evaluation is the following:

(1) To estimate the loss of pulmonary function and the consequent limitations in quality of life following lung resection.

(2) To predict the risk of early mortality and major complications as well as long-term survival. 
(3) To identify patients who might benefit from riskreducing interventions.

Postoperative lung function $\left(\mathrm{ppoFEV}_{1}\right.$ and $\mathrm{ppoD}_{\mathrm{LCO}}$ ) can be evaluated by combining the results of chest-CT scans with measurements of lung volumes $\left(\mathrm{FEV}_{1}\right)$ and diffusion capacity $\left(\mathrm{D}_{\mathrm{LCO}}\right)$. With the recent advances in minimal-invasive surgery, the early reduction in pulmonary function can be partially attenuated while fast-track anesthesia and rehabilitation programs may further speed up the recovery process.

Assessment of cardiac function and aerobic capacity is of paramount importance for clearing the patient for surgery and also for guiding further optimization therapy. Strong evidence indicates that a $\mathrm{VO}_{2} \max >20 \mathrm{ml} \times \mathrm{kg}^{-1} \times \mathrm{min}^{-1}$ (or $>22 \mathrm{~m}$ climbing ascent) qualifies the patient for any major lung resection whereas a $\mathrm{VO}_{2} \max <10 \mathrm{ml} \times \mathrm{kg}^{-1} \times \min ^{-1}$ identifies the "very high-risk" patient. Preliminary reports lend support to the benefits of a preoperative short-term rehabilitation program. Indeed, significant improvements in $\mathrm{VO}_{2}$ max and in muscular strength have been demonstrated among patients with NSCLC undergoing a high-intensity training program [90]. Further prospective randomized trials are warranted in this field in order to increase the number of candidates for curative surgical resection.

\section{Compliance with Ethics Guidelines}

Conflict of Interest Marc Licker, Frédéric Triponez, John Diaper, Wolfram Karenovics declares that he has no conflict of interest. Pierre-Olivier Bridevaux has received compensation from Boehringer Ingelheim for providing expert testimony as part of an advisory board and has received payment for lectures including service on speakers bureaus from GlaxoSmithKline and AstraZeneca.

Human and Animal Rights and Informed Consent This article does not contain any studies with human or animal subjects performed by any of the authors.

\section{References}

Papers of particular interest, published recently, have been highlighted as:

- Of importance

1. United States Cancer Statistics: 1999-2010 Incidence and Mortality Web-based Report. Department of Health and Human Services, Centers for Disease Control and Prevention, and National Cancer Institute 2013.

2. Erridge SC, Moller H, Price A, Brewster D. International comparisons of survival from lung cancer: pitfalls and warnings. Nat Clin Pract Oncol. 2007;4(10):570-7.

3. Riaz SP, Luchtenborg M, Jack RH, Coupland VH, Linklater KM, Peake MD, Moller H. Variation in surgical resection for lung cancer in relation to survival: population-based study in England 2004-2006. Eur J Cancer. 2012;48(1):54-60.
4. Thorsteinsson H, Alexandersson A, Oskarsdottir GN, Skuladottir $\mathrm{R}$, Isaksson HJ, Jonsson S, Gudbjartsson T. Resection rate and outcome of pulmonary resections for non-small-cell lung cancer: a nationwide study from Iceland. J Thorac Oncol. 2012;7(7): 1164-9.

5. Boffa DJ, Allen MS, Grab JD, Gaissert HA, Harpole DH, Wright CD. Data from The Society of Thoracic Surgeons General Thoracic Surgery database: the surgical management of primary lung tumors. J Thorac Cardiovasc Surg. 2008;135(2):247-54.

6. Licker MJ, Widikker I, Robert J, Frey JG, Spiliopoulos A, Ellenberger C, Schweizer A, Tschopp JM. Operative mortality and respiratory complications after lung resection for cancer: impact of chronic obstructive pulmonary disease and time trends. Ann Thorac Surg. 2006;81(5):1830-7.

7. - Falcoz PE, Conti M, Brouchet L, Chocron S, Puyraveau M, Mercier M, Etievent JP, Dahan M. The Thoracic Surgery Scoring System (Thoracoscore): risk model for in-hospital death in 15,183 patients requiring thoracic surgery. J Thorac Cardiovasc Surg. 2007;133(2):325-332. The Thoracoscore was derived from the French national thoracic database (2002-2005; cancer and non-cancer in dications), and it has good performance characteristics for predicting the risk of operative death.

8. Bernard A, Rivera C, Pages PB, Falcoz PE, Vicaut E, Dahan M. Risk model of in-hospital mortality after pulmonary resection for cancer: a national database of the French Society of Thoracic and Cardiovascular Surgery (Epithor). J Thorac Cardiovasc Surg. 2011;141(2):449-58.

9. - Powell HA, Tata LJ, Baldwin DR, Stanley RA, Khakwani A, Hubbard RB. Early mortality after surgical resection for lung cancer: an analysis of the English National Lung cancer audit. Thorax. 2013;68(9):826-834. Data from the British National Lung Cancer Audit including all patients with NSCLC (20042010) were used to develop a predictive score of operative death within 30 days and 90 days after lung resection surgery.

10. Raman T, Roistacher N, Liu J, Zhang H, Shi W, Thaler HT, Amar D. Preoperative left atrial dysfunction and risk of postoperative atrial fibrillation complicating thoracic surgery. J Thorac Cardiovasc Surg. 2012;143(2):482-7.

11. Bryant AS, Rudemiller K, Cerfolio RJ. The 30- versus 90-day operative mortality after pulmonary resection. Ann Thorac Surg. 2010;89(6):1717-22 discussion 1722-1713.

12. Licker M, Fauconnet P, Villiger Y, Tschopp JM. Acute lung injury and outcomes after thoracic surgery. Curr Opin Anaesthesiol. 2009;22(1):61-7.

13. Fleisher LA, Beckman JA, Brown KA, Calkins H, Chaikof EL, Fleischmann KE, Freeman WK, Froehlich JB, Kasper EK, Kersten JR et al. ACC/AHA 2007 Guidelines on Perioperative Cardiovascular Evaluation and Care for Noncardiac Surgery: Executive Summary: A Report of the American College of Cardiology/American Heart Association Task Force on Practice Guidelines (Writing Committee to Revise the 2002 Guidelines on Perioperative Cardiovascular Evaluation for Noncardiac Surgery) Developed in Collaboration With the American Society of Echocardiography, American Society of Nuclear Cardiology, Heart Rhythm Society, Society of Cardiovascular Anesthesiologists, Society for Cardiovascular Angiography and Interventions, Society for Vascular Medicine and Biology, and Society for Vascular Surgery. J Am Coll Cardiol. 2007;50(17):1707-1732.

14. Brunelli A, Varela G, Salati M, Jimenez MF, Pompili C, Novoa N, Sabbatini A. Recalibration of the revised cardiac risk index in lung resection candidates. Ann Thorac Surg. 2010;90(1): 199-203.

15. Ferguson MK, Celauro AD, Vigneswaran WT. Validation of a modified scoring system for cardiovascular risk associated with major lung resection. Eur J Cardiothorac Surg. 2012;41(3): 598-602. 
16. Singla S, Sachdeva R, Uretsky BF. The risk of adverse cardiac and bleeding events following noncardiac surgery relative to antiplatelet therapy in patients with prior percutaneous coronary intervention. J Am Coll Cardiol. 2012;60(20):2005-16.

17. Meyer S, McLaughlin VV, Seyfarth HJ, Bull TM, Vizza CD, Gomberg-Maitland M, Preston IR, Barbera JA, Hassoun PM, Halank M, et al. Outcomes of noncardiac, non obstetric surgery in patients with PAH: an international prospective survey. Eur Respir J. 2013;41(6):1302-7.

18. Minai OA, Yared JP, Kaw R, Subramaniam K, Hill NS. Perioperative risk and management in patients with pulmonary hypertension. Chest. 2013;144(1):329-40.

19. Wei B, D'Amico T, Samad Z, Hasan R, Berry MF. The impact of pulmonary hypertension on morbidity and mortality following major lung resection. Eur J Cardiothorac Surg. 2013. doi:10. 1093/ejcts/ezt495.

20. Canet J, Gallart L, Gomar C, Paluzie G, Valles J, Castillo J, Sabate S, Mazo V, Briones Z, Sanchis J. Prediction of postoperative pulmonary complications in a population-based surgical cohort. Anesthesiology. 2010;113(6):1338-50.

21. Launer H, Nguyen DV, Cooke DT. National perioperative outcomes of pulmonary lobectomy for cancer in the obese patient: a propensity score matched analysis. J Thorac Cardiovasc Surg. 2013;145(5):1312-8.

22. Ceppa DP, Kosinski AS, Berry MF, Tong BC, Harpole DH, Mitchell JD, D'Amico TA, Onaitis MW. Thoracoscopic lobectomy has increasing benefit in patients with poor pulmonary function: a Society of Thoracic Surgeons Database analysis. Ann Surg. 2012;256(3):487-93.

23. Ruppel GL, Enright PL. Pulmonary function testing. Respir Care. 2012;57(1):165-75.

24. Stanojevic S, Wade A, Stocks J, Hankinson J, Coates AL, Pan H, Rosenthal M, Corey M, Lebecque P, Cole TJ. Reference ranges for spirometry across all ages: a new approach. Am J Respir Crit Care Med. 2008;177(3):253-60.

25. Aggarwal AN, Agarwal R. The new ATS/ERS guidelines for assessing the spirometric severity of restrictive lung disease differ from previous standards. Respirology. 2007;12(5):759-62.

26. - Vestbo J, Hurd SS, Agusti AG, Jones PW, Vogelmeier C, Anzueto A, Barnes PJ, Fabbri LM, Martinez FJ, Nishimura M et al. Global strategy for the diagnosis, management, and prevention of chronic obstructive pulmonary disease: GOLD executive summary. Am J Respir Crit Care Med. 2013;187(4): 347-365. Since 2001, the Global Initiative for Chronic Obstructive Lung Disease (GOLD) has published and updated evidence-based strategies for the diagnosis and management of chronic obstructive pulmonary diseases.

27. Gardner ZS, Ruppel GL, Kaminsky DA. Grading the severity of obstruction in mixed obstructive-restrictive lung disease. Chest. 2011;140(3):598-603.

28. Armstrong C. ACP updates guideline on diagnosis and management of stable COPD. Am Fam Physician. 2011;85(2):204-5.

29. Casanova C, Aguirre-Jaime A, de Torres J, Pinto-Plata V, Baz R, Marin J, Divo M, Cordoba E, Basaldua S, Cote C et al: Longitudinal assessment in COPD patients: multidimensional variability and outcomes. Eur Respir J. 2013. doi:10.1183/09031936.00096913.

30. Esteban C, Quintana JM, Aburto M, Moraza J, Arostegui I, Espana PP, Aizpiri S, Capelastegui A. The health, activity, dyspnea, obstruction, age, and hospitalization: prognostic score for stable COPD patients. Respir Med. 2011;105(11):1662-70.

31. Jensen RL, Crapo RO. Diffusing capacity: how to get it right. Respir Care. 2003;48(8):777-82.

32. Macintyre N, Crapo RO, Viegi G, Johnson DC, van der Grinten CP, Brusasco V, Burgos F, Casaburi R, Coates A, Enright P, et al. Standardisation of the single-breath determination of carbon monoxide uptake in the lung. Eur Respir J. 2005;26(4):720-35.
33. Hughes JM. The single breath transfer factor (Tl, co) and the transfer coefficient (Kco): a window onto the pulmonary microcirculation. Clin Physiol Funct Imaging. 2003;23(2):63-71.

34. Milledge JS, Nunn JF. Criteria of fitness for anaesthesia in patients with chronic obstructive lung disease. Br Med J. 1975; 3(5985):670-3.

35. Nafiu OO, Ramachandran SK, Ackwerh R, Tremper KK, Campbell DA Jr, Stanley JC. Factors associated with and consequences of unplanned post-operative intubation in elderly vascular and general surgery patients. Eur J Anaesthesiol. 2011;28(3):220-4.

36. Lalley PM. The aging respiratory system-pulmonary structure, function and neural control. Respir Physiol Neurobiol. 2013; 187(3):199-210.

37. Cowley NJ, Owen A, Bion JF. Interpreting arterial blood gas results. BMJ. 2013;346:f16.

38. Young IH, Bye PT. Gas exchange in disease: asthma, chronic obstructive pulmonary disease, cystic fibrosis, and interstitial lung disease. Compr Physiol. 2011;1(2):663-97.

39. Brunelli A, Refai MA, Salati M, Sabbatini A, Morgan-Hughes NJ, Rocco G. Carbon monoxide lung diffusion capacity improves risk stratification in patients without airflow limitation: evidence for systematic measurement before lung resection. Eur J Cardiothorac Surg. 2006;29(4):567-70.

40. British Thoracic Society; Society of Cardiothoracic Surgeons of Great Britain and Ireland Working Party. BTS guidelines: guidelines on the selection of patients with lung cancer for surgery. Thorax. 2001;56(2):89-108.

41. Brunelli A, Charloux A, Bolliger CT, Rocco G, Sculier JP, Varela G, Licker M, Ferguson MK, Faivre-Finn C, Huber RM, et al. ERS/ESTS clinical guidelines on fitness for radical therapy in lung cancer patients (surgery and chemo-radiotherapy). Eur Respir J. 2009;34(1):17-41.

42. Liang BM, Lam DC, Feng YL. Clinical applications of lung function tests: a revisit. Respirology. 2012;17(4):611-9.

43. Wang T, Tagayun A, Bogardus A, Qian D, Tiep B, Horak D, Grannis FW Jr. How accurately can we predict forced expiratory volume in one second after major pulmonary resection? Am Surg. 2007;73(10): 1047-51.

44. Corris PA, Ellis DA, Hawkins T, Gibson GJ. Use of radionuclide scanning in the preoperative estimation of pulmonary function after pneumonectomy. Thorax. 1987;42(4):285-91.

45. Yoshimoto K, Nomori H, Mori T, Kobayashi H, Ohba Y, Shibata $\mathrm{H}$, Shiraishi S, Kobayashi T. Prediction of pulmonary function after lung lobectomy by subsegments counting, computed tomography, single photon emission computed tomography and computed tomography: a comparative study. Eur J Cardiothorac Surg. 2009;35(3):408-13.

46. Ohno Y, Koyama H, Nogami M, Takenaka D, Matsumoto S, Yoshimura M, Kotani Y, Sugimura K. Postoperative lung function in lung cancer patients: comparative analysis of predictive capability of MRI, CT, and SPECT. AJR Am J Roentgenol. 2007;189(2):400-8.

47. - Brunelli A, Kim AW, Berger KI, Addrizzo-Harris DJ. Physiologic evaluation of the patient with lung cancer being considered for resectional surgery: Diagnosis and management of lung cancer, 3rd ed: American College of Chest Physicians evidencebased clinical practice guidelines. Chest 2013;143(5 Sup$\mathrm{pl}): \mathrm{e} 166 \mathrm{~S}-190 \mathrm{~S}$. Most recent updated guidelines of preoperative physiologic assessment to identify patients at increased risk of perioperative major complications. A stepwise integrative approach is described that emphasizes the importance of ppoFEV1, ppoDLCO and exercise testing.

48. Varela G, Brunelli A, Rocco G, Marasco R, Jimenez MF, Sciarra V, Aranda JL, Gatani T. Predicted versus observed FEV1 in the immediate postoperative period after pulmonary lobectomy. Eur J Cardiothorac Surg. 2006;30(4):644-8. 
49. Phillips JD, Merkow RP, Sherman KL, DeCamp MM, Bentrem DJ, Bilimoria KY. Factors affecting selection of operative approach and subsequent short-term outcomes after anatomic resection for lung cancer. J Am Coll Surg. 2012;215(2):206-15.

50. Licker M, Diaper J, Villiger Y, Spiliopoulos A, Licker V, Robert J, Tschopp JM. Impact of intraoperative lung-protective interventions in patients undergoing lung cancer surgery. Crit Care. 2009;13(2):R41.

51. Campos JH. Fast track in thoracic anesthesia and surgery. Curr Opin Anaesthesiol. 2009;22(1):1-3.

52. Whitson BA, Groth SS, Duval SJ, Swanson SJ, Maddaus MA. Surgery for early-stage non-small cell lung cancer: a systematic review of the video-assisted thoracoscopic surgery versus thoracotomy approaches to lobectomy. Ann Thorac Surg. 2008;86(6): 2008-16 discussion 2016-2008.

53. Brunelli A, Refai M, Salati M, Xiume F, Sabbatini A. Predicted versus observed FEV1 and DLCO after major lung resection: a prospective evaluation at different postoperative periods. Ann Thorac Surg. 2007;83(3):1134-9.

54. Choong CK, Meyers BF, Battafarano RJ, Guthrie TJ, Davis GE, Patterson GA, Cooper JD. Lung cancer resection combined with lung volume reduction in patients with severe emphysema. J Thorac Cardiovasc Surg. 2004;127(5):1323-31.

55. Iorio A, Magri D, Paolillo S, Salvioni E, Di Lenarda A, Sinagra G, Agostoni P, Sciomer S. Rationale for cardiopulmonary exercise test in the assessment of surgical risk. J Cardiovasc Med. 2013;14(4):254-61.

56. Arena R, Myers J, Williams MA, Gulati M, Kligfield P, Balady GJ, Collins E, Fletcher G. Assessment of functional capacity in clinical and research settings: a scientific statement from the American Heart Association Committee on Exercise, Rehabilitation, and Prevention of the Council on Clinical Cardiology and the Council on Cardiovascular Nursing. Circulation. 2007;116(3):329-43.

57. Bruce RA, Kusumi F, Hosmer D. Maximal oxygen intake and nomographic assessment of functional aerobic impairment in cardiovascular disease. Am Heart J. 1973;85(4):546-62.

58. Guazzi M, Adams V, Conraads V, Halle M, Mezzani A, Vanhees L, Arena R, Fletcher GF, Forman DE, Kitzman DW, et al. EACPR/AHA Scientific Statement. Clinical recommendations for cardiopulmonary exercise testing data assessment in specific patient populations. Circulation. 2012;126(18):2261-74.

59. Waschki B, Kirsten A, Holz O, Muller KC, Meyer T, Watz H, Magnussen $\mathrm{H}$. Physical activity is the strongest predictor of allcause mortality in patients with COPD: a prospective cohort study. Chest. 2011;140(2):331-42.

60. Cahalin LP, Chase P, Arena R, Myers J, Bensimhon D, Peberdy MA, Ashley E, West E, Forman DE, Pinkstaff S, et al. A metaanalysis of the prognostic significance of cardiopulmonary exercise testing in patients with heart failure. Heart Fail Rev. 2013;18(1):79-94.

61. Arena R, Sietsema KE. Cardiopulmonary exercise testing in the clinical evaluation of patients with heart and lung disease. Circulation. 2011;123(6):668-80.

62. Sin DD, Man SF. Skeletal muscle weakness, reduced exercise tolerance, and COPD: is systemic inflammation the missing link? Thorax. 2006;61(1):1-3.

63. Midgley AW, Mc Naughton LR. Time at or near $\mathrm{VO}_{2}$ max during continuous and intermittent running. A review with special reference to considerations for the optimisation of training protocols to elicit the longest time at or near $\mathrm{VO}_{2}$ max. J Sports Med Phys fit. 2006;46(1):1-14.

64. Cataneo DC, Kobayasi S, Carvalho LR, Paccanaro RC, Cataneo AJ. Accuracy of 6 min walk test, stair test and spirometry using maximal oxygen uptake as gold standard. Acta cirurgica brasileira/Sociedade Brasileira para Desenvolvimento Pesquisa em Cirurgia. 2010;25(2):194-200.
65. Bernasconi $\mathrm{M}$, Koegelenberg $\mathrm{CF}$, von Groote-Bidlingmaier $\mathrm{F}$, Maree D, Barnard BJ, Diacon AH, Bolliger CT. Speed of ascent during stair climbing identifies operable lung resection candidates. Respiration. 2012;84(2):117-22.

66. Brunelli A, Xiume F, Refai M, Salati M, Di Nunzio L, Pompili C, Sabbatini A. Peak oxygen consumption measured during the stairclimbing test in lung resection candidates. Respiration. 2010; 80(3):207-11.

67. Campo LA, Chilingaryan G, Berg K, Paradis B, Mazer B. Validity and reliability of the modified shuttle walk test in patients with chronic obstructive pulmonary disease. Arch Phys Med Rehabil. 2006;87(7):918-22.

68. Singh SJ, Morgan MD, Hardman AE, Rowe C, Bardsley PA. Comparison of oxygen uptake during a conventional treadmill test and the shuttle walking test in chronic airflow limitation. Eur Respir J. 1994;7(11):2016-20.

69. Carter R, Holiday DB, Grothues C, Nwasuruba C, Stocks J, Tiep B. Criterion validity of the Duke Activity Status Index for assessing functional capacity in patients with chronic obstructive pulmonary disease. J Cardpulm Rehabil. 2002;22(4):298-308.

70. Kodama S, Saito K, Tanaka S, Maki M, Yachi Y, Asumi M, Sugawara A, Totsuka K, Shimano H, Ohashi Y, et al. Cardiorespiratory fitness as a quantitative predictor of all-cause mortality and cardiovascular events in healthy men and women: a metaanalysis. JAMA. 2009;301(19):2024-35.

71. Hamaker ME, Jonker JM, de Rooij SE, Vos AG, Smorenburg CH, van Munster BC. Frailty screening methods for predicting outcome of a comprehensive geriatric assessment in elderly patients with cancer: a systematic review. Lancet Oncol. 2012;13(10):e437-44.

72. Brunelli A, Al Refai M, Monteverde M, Sabbatini A, Xiume F, Fianchini A. Predictors of early morbidity after major lung resection in patients with and without airflow limitation. Ann Thorac Surg. 2002;74(4):999-1003.

73. Berry MF, Villamizar-Ortiz NR, Tong BC, Burfeind WR Jr, Harpole DH, D'Amico TA, Onaitis MW. Pulmonary function tests do not predict pulmonary complications after thoracoscopic lobectomy. Ann Thorac Surg. 2010;89(4):1044-51 discussion 1051-1042.

74. Ferguson MK, Dignam JJ, Siddique J, Vigneswaran WT, Celauro AD. Diffusing capacity predicts long-term survival after lung resection for cancer. Eur J Cardiothorac Surg. 2012;41(5):e81-6.

75. Liptay MJ, Basu S, Hoaglin MC, Freedman N, Faber LP, Warren WH, Hammoud ZT, Kim AW. Diffusion lung capacity for carbon monoxide (DLCO) is an independent prognostic factor for longterm survival after curative lung resection for cancer. J Surg Oncol. 2009;100(8):703-7.

76. Jensen MB, Houborg KB, Norager CB, Henriksen MG, Laurberg $\mathrm{S}$. Postoperative changes in fatigue, physical function and body composition: an analysis of the amalgamated data from five randomized trials on patients undergoing colorectal surgery. Colorectal Dis. 2011;13(5):588-93.

77. Brandi LS, Bertolini R, Janni A, Gioia A, Angeletti CA. Energy metabolism of thoracic surgical patients in the early postoperative period. Effect of posture. Chest. 1996;109(3):630-7.

78. Sasaki N, Meyer MJ, Eikermann M. Postoperative respiratory muscle dysfunction: pathophysiology and preventive strategies. Anesthesiology. 2013;118(4):961-78.

79. Colson M, Baglin J, Bolsin S, Grocott MP. Cardiopulmonary exercise testing predicts 5 year survival after major surgery. Br J Anaesth. 2012;109(5):735-41.

80. Hartley RA, Pichel AC, Grant SW, Hickey GL, Lancaster PS, Wisely NA, McCollum CN, Atkinson D. Preoperative cardiopulmonary exercise testing and risk of early mortality following abdominal aortic aneurysm repair. Br J Surg. 2012;99(11):1539-46.

81. Moyes LH, McCaffer CJ, Carter RC, Fullarton GM, Mackay CK, Forshaw MJ. Cardiopulmonary exercise testing as a predictor of 
complications in oesophagogastric cancer surgery. Ann R Coll Surg Engl. 2013;95(2):125-30.

82. Smith TB, Stonell C, Purkayastha S, Paraskevas P. Cardiopulmonary exercise testing as a risk assessment method in non cardio-pulmonary surgery: a systematic review. Anaesthesia. 2009;64(8):883-93.

83. Thorp AA, Owen N, Neuhaus M, Dunstan DW. Sedentary behaviors and subsequent health outcomes in adults a systematic review of longitudinal studies, 1996-2011. Am J Prev Med. 2011;41(2):207-15.

84. Brunelli A, Belardinelli R, Refai M, Salati M, Socci L, Pompili C, Sabbatini A. Peak oxygen consumption during cardiopulmonary exercise test improves risk stratification in candidates to major lung resection. Chest. 2009;135(5):1260-7.

85. Licker M, Schnyder JM, Frey JG, Diaper J, Cartier V, Inan C, Robert J, Bridevaux PO, Tschopp JM. Impact of aerobic exercise capacity and procedure-related factors in lung cancer surgery. Eur Respir J. 2012;37(5):1189-98.
86. Benzo R, Kelley GA, Recchi L, Hofman A, Sciurba F. Complications of lung resection and exercise capacity: a meta-analysis. Respir Med. 2007;101(8):1790-7.

87. Brunelli A, Refai M, Xiume F, Salati M, Sciarra V, Socci L, Sabbatini A. Performance at symptom-limited stair-climbing test is associated with increased cardiopulmonary complications, mortality, and costs after major lung resection. Ann Thorac Surg. 2008;86((1):240-7 discussion 247-248.

88. Brunelli A. Algorithm for functional evaluation of lung resection candidates: time for reappraisal? Respiration. 2009;78(1):117-8.

89. Win T, Jackson A, Sharples L, Groves AM, Wells FC, Ritchie AJ, Laroche CM. Cardiopulmonary exercise tests and lung cancer surgical outcome. Chest. 2005;127(4):1159-65.

90. Stefanelli F, Meoli I, Cobuccio R, Curcio C, Amore D, Casazza D, Tracey M, Rocco G. High-intensity training and cardiopulmonary exercise testing in patients with chronic obstructive pulmonary disease and non-small-cell lung cancer undergoing lobectomy. Eur J Cardiothorac Surg. 2013;44(4):e260-5. 